\title{
ZNAČILNOSTI OPRAVLJANJA SEČNJE IN SPRAVILA V ZASEBNIH GOZDOVIH V SLOVENIJI
}

\section{CHARACTERISATION OF FELLING AND SKIDDING IN PRIVATE FORESTS IN SLOVENIA}

\author{
Špela ŠČAP ${ }^{1}$, Darja STARE 2 , Nike KRAJNC ${ }^{3}$, Matevž TRIPLAT ${ }^{4}$ \\ (1) Gozdarski inštitut Slovenije, spela.scap@gozdis.si \\ (2) Gozdarski inštitut Slovenije, darja.stare@gozdis.si \\ (3) Gozdarski inštitut Slovenije, nike.krajnc@gozdis.si \\ (4) Gozdarski inštitut Slovenije, matevz.triplat@gozdis.si
}

\begin{abstract}
IZVLEČEK
V raziskavi, opravljeni leta 2019, je bilo zajetih 544 naključno izbranih gospodinjstev, ki imajo v lasti gozd. Več kot polovica anketiranih ima v lasti gozdno posest, veliko od 1 do 4,99 ha. Za $62 \%$ anketiranih je glavni namen gospodarjenja z gozdom uporaba lesa za lastne potrebe. V obdobju 2015-2019 je sečnjo in spravilo opravljalo $71 \%$ anketiranih, ki so v tem času skupaj posekali nekaj manj kot $50.000 \mathrm{~m}^{3}$ lesa $\left(24 \mathrm{~m}^{3} /\right.$ ha ali $141 \mathrm{~m}^{3}$ na gospodinjstvo). Intenziteta sečnje je bila najvišja pri zasebnih lastnikih z malimi gozdnimi posestmi (do 0,99 ha), in sicer v povprečju $41,4 \mathrm{~m}^{3} / \mathrm{ha}$. Analiza je pokazala, da obstajajo statistično značilne razlike med velikostjo gozdne posesti in intenziteto sečnje. V anketi je bilo ugotovljeno, da so za $41 \%$ sečnje in spravila poskrbeli poklicni izvajalci del. Z raziskavo smo potrdili značilen vpliv velikosti zasebne gozdne posesti na način izvedbe sečnje in spravila. Rezultati so pokazali, da je največji delež zasebnih lastnikov, ki vsa dela opravijo s pomočjo najetih izvajalcev, v velikostnem razredu gozdne posesti od 5 do 9,99 ha. Z raziskavo nismo potrdili statistično značilnih razlik v intenziteti sečnje med spoloma zasebnih lastnikov gozdov.
\end{abstract}

Ključne besede: zasebni lastniki, anketa, intenziteta sečnje, struktura lastnikov, gozdna posest, sečnja in spravilo v zasebnih gozdovih

\section{IZVLEČEK}

A survey conducted in 2019 covered 544 randomly selected forest owners. More than half of the forest owners own a forest estate ranging from 1 to 4.99 ha. For $62 \%$ of respondents, the primary purpose of forest management is to harvest wood for their own needs. In 2015-2019, $71 \%$ of respondents carried out felling and skidding in their forests. In total, approximately $50,000 \mathrm{~m}^{3}$ of wood was felled $\left(24 \mathrm{~m}^{3} /\right.$ ha or $141 \mathrm{~m}^{3}$ per holding). The largest volumes were felled by private owners with small forest holdings (up to $0.99 \mathrm{ha}$ ), on average $41.4 \mathrm{~m}^{3} / \mathrm{ha}$. There were statistically significant differences between the size of the forest holding and the average volume of annual felling. Furthermore, there were no statistically significant differences in felling intensity between male and female forest owners. The survey found that professional contractors carried out $41 \%$ of felling and harvesting. Furthermore, there were significant differences between the size of the private forest estate and the method of performing forest operations. The results showed that the largest share of private owners who carry out all felling and skidding with the help of hired contractors is in the size class of forest holdings from 5 to 9.99 ha. The study did not confirm statistically significant differences in the intensity of felling between male and female private forest owners.

Key words: private forest owners, questionnaire, intensity of felling, structure of forest owners, forest estate, forest operations in privately owned forests, felling and skidding

GDK 3:682(497.4)(045)=163.6

Prispelo / Received: 25. 2. 2021

DOI 10.20315/ASetL.125.3

Sprejeto / Accepted: 27. 5. 2021

\section{INTRODUCTION}

\section{UVOD}

Površina zasebnih gozdov v Sloveniji se je v zadnjih desetletjih povečala, število zasebnih lastnikov gozdov pa je narastlo, posledično se je povečala razdrobljenost gozdne posesti. Delež zasebnih gozdov je leta 1996 znašal 66,1 \%, leta 2019 pa kar 79,7 \% (Poročilo ..., 2020). Ob tako velikem deležu zasebnih gozdov je po- membno vprašanje, kdo opravlja dela v zasebnih gozdovih. V Sloveniji se po podatkih Zavoda za gozdove Slovenije (ZGS) spoprijemamo z nizko realizacijo načrtovanega poseka (Poročilo ..., 2020). Na sečnjo in spravilo v zasebnih gozdovih vplivajo različni ekonomski, posestni in naravni dejavniki (Poje in sod., 2016). Za Slovenijo značilna razdrobljenost in majhnost zasebne gozdne posesti zmanjšuje racionalnost dela in vpliva 
na opravljanje del v zasebnih gozdovih. Prav tako socialne, demografske in ekonomske značilnosti zasebnih lastnikov gozdov pomembno vplivajo na gospodarjenje z gozdovi (Ficko, 2019). Pripravljenost zasebnih lastnikov gozdov za gospodarjenje in njihov odnos do gozda pa sta ključna za zagotavljanje lesa iz zasebnih gozdov (Češarek in sod., 2018).

Starejše raziskave (npr. Winkler, 1976; Medved, 1991; Medved, 2000; Medved, 2003; Robek in sod., 2005; Rutar, 2010) kažejo, da večino del v gozdovih opravijo lastniki sami, s pomočjo družinskih članov ali v okviru medsosedske pomoči. Rutar (2010) je v svoji raziskavi ugotovila, da večina zasebnih lastnikov gozdov dela $\mathrm{v}$ gozdu v dvojicah, to so predvsem tisti z večjo gozdno posestjo (nad 6 ha). Tisti z najmanjšo gozdno posestjo pa največkrat delajo sami. Tudi novejše študije (Statistični urad ..., 2021) potrjujejo, da večino del opravijo zasebni lastniki gozdov sami. V letu 2016 so zasebni lastniki gozdov v okviru kmetijskih gospodarstev večino dela v gozdu opravili sami z družinskimi člani, najeto delo je dosegalo le 7 \% vsega opravljenega dela. Kljub nizkemu deležu najema izvajalcev za delo v gozdu njihovo število v zadnjih letih narašča (Triplat in Krajnc, 2021).

Dandanes je nemogoče pričakovati, da bodo vsi zasebni lastniki gozdov opravljali dela v svojem gozdu sami ali, še pomembneje, da bi bili vsi ustrezno opremljeni in usposobljeni za delo. Pri tem je pomembno, da je delo $v$ gozdu v prvi vrsti varno in zdravju neškodljivo ter $\mathrm{v}$ drugi vrsti tudi ekonomsko učinkovito. Korbar (2005) precejšnjo nezainteresiranost zasebnih lastnikov gozdov pojasnjuje $\mathrm{z}$ gozdarskim sistemom v prejšnjem režimu (pred letom 1991). Ta je lastniku na eni strani omejeval pravico do gospodarjenja z gozdom in samostojno prodajo lesa, na drugi strani pa je na celotni površini gozdov ne glede na lastništvo opravljal vsa potrebna dela (npr. sečnja in spravilo, graditev prometnic). Ta način se ohranja tudi v novem sistemu z Zakonom o gozdovih (1993) in Programom razvoja gozdov v Sloveniji (1996), saj javna gozdarska služba zagotavlja načrtovanje, odkazilo in terensko gozdarsko službo ter ohranja sorazmerno pasivnega gozdnega posestnika. Na drugi strani področje dela zasebnih lastnikov gozdov v lastnih gozdovih in prek medsoseske pomoči ni doživelo jasne zakonske opredelitve zahtev po strokovni usposobljenosti in tehnični opremljenosti (Korbar, 2005), medtem ko morajo izvajalci gozdarskih del upoštevati zakonodajo in izpolnjevati minimalne pogoje za delo v gozdovih (Triplat in Krajnc, 2021).

V EU je kar $60 \%$ gozdov v zasebni lasti in vse več raziskav je namenjenih razumevanju gospodarjenja in opravljanja del v zasebnih gozdovih (npr. Nichiforel in sod., 2018; Ficko, 2019). Več raziskav je bilo name- njenih predvsem ugotavljanju vplivnih dejavnikov na način gospodarjenja zasebnih lastnikov gozdov z njihovim gozdom (npr. Beach in sod., 2005; Andersson in sod., 2010; Aguilar in sod., 2014; Petucco in sod., 2015; Kilham in sod., 2019; Bashir in sod., 2020; Juutinen in sod., 2020). Tako raziskovalci v tujini ugotavljajo, da k opravljanju sečnje in spravila zasebne lastnike gozdov spodbudijo različni dejavniki in da gre navadno za kompromis med različnimi željami in potrebami, hkrati pa način gospodarjenja izvira iz njihovega odziva na spreminjajoče se okoliščine in spodbude ali ovire $v$ okolju. Tudi raziskovalci v Sloveniji so pri preučevanju gospodarjenja $\mathrm{v}$ zasebnih gozdovih in vplivnih dejavnikov na sečnjo v zasebnih gozdovih prišli do podobnih spoznanj (npr. Pezdevšek Malovrh, 2010; Poje in sod., 2016; Češarek in sod., 2018; Ficko, 2019; Kumer, 2019). Poje s sodelavci (2016) celo ugotavlja, da so dejavniki, ki vplivajo na sečnjo v zasebnih gozdovih, na splošno povsod po svetu enaki. Vse večja heterogenost zasebnih lastnikov gozdov se kaže v njihovem odnosu do gospodarjenja, ta pa se zaradi različnih dejavnikov nenehno spreminja (Pezdevšek Malovrh in sod., 2015; Kumer in Pezdevšek Malovrh, 2019). Poleg tega se tudi zasebni lastnik gozda skozi čas spreminja, zato se spreminjajo tudi njegove odločitve (Kilham in sod., 2019). Še več, v mnogih državah se lastništvo gozdov spreminja na račun večjega deleža ženskih lastnic gozdov, lastnikov, ki živijo v mestu, in lastnikov brez kakršnegakoli gozdarskega znanja. Kot posledica tega pa se kaže, da je na trgu vse več ponudb gozdarskih storitev namenjenih zasebnim lastnikom gozdov (Andersson in H. Keskitalo, 2019). Zanimiva študija, ki je potekala na evropski ravni, se je ukvarjala z vprašanjem lastninske pravice zasebnih lastnikov gozdov (Nichiforel in sod., 2018). Rezultati so pokazali presenetljive razlike v stopnji svobode, ki jo imajo zasebni lastniki gozdov v posameznih evropskih državah ali regijah. Lastninska pravica vključuje tudi pravico do sečnje in spravila lesa, priprave lesnih goriv in pridobivanja nelesnih gozdnih proizvodov. Zato lahko zagotovo trdimo le, da med različnimi evropskimi državami obstajajo razlike v opravljanju del v zasebnih gozdovih.

0 gozdnih ekosistemih vemo že veliko, na drugi strani pa zelo malo o ljudeh, ki so lastniki velikega dela gozdnih površin (Ficko, 2019). Zato poznavanje, kdo opravlja dela v zasebnih gozdovih, pomembno prispeva k poznavanju področja zasebnega lastništva gozdov ter spoprijemanju z vse večjo heterogenostjo zasebnih lastnikov gozdov in njihovim spreminjajočim se odnosom do gospodarjenja z gozdom. Z namenom ugotoviti stanje na področju opravljanja del v zasebnih gozdovih smo napravili raziskavo med naključnimi gospodinjstvi 
na območju celotne Slovenije. Vzorec raziskave so predstavljala gospodinjstva, ki imajo v lasti gozd, znotraj gospodinjstva pa je na vprašalnik odgovarjala oseba, ki z gozdom gospodari. Z raziskavo želimo dobiti boljši vpogled v značilnosti opravljanja sečnje in spravila v zasebnih gozdovih v Sloveniji. V ospredju naše raziskave sta torej dva cilja: 1.) ugotoviti, kdo opravlja dela v zasebnih gozdovih, ter 2.) pojasniti, kateri dejavniki vplivajo na intenziteto gospodarjenja $v$ zasebnih gozdovih. Poleg zastavljenih ciljev pa smo z raziskavo med zasebnimi lastniki gozdov želeli preveriti naslednje hipoteze:

- Velikost gozdne posesti vpliva na intenziteto sečnje v zasebnih gozdovih.

- Večji zasebni lastniki gozdov (v lasti 5 ha gozda ali več) pogosteje najemajo gozdarske storitve kot manjši zasebni lastniki gozdov.

- Moški zasebni lastniki gozdov bolj intenzivno gospodarijo z gozdovi kot ženske lastnice gozdov in so tudi bolj tržno usmerjeni.

\section{METODE}

2 METHODS

Z namenom ugotoviti stanje glede sečnje in spravila lesa v zasebnih gozdovih smo septembra 2019 opravili obširno anketiranje med naključnimi gospodinjstvi na območju celotne Slovenije. Za pomoč pri oblikovanju vprašalnika nam je prišla prav podobna raziskava, ki smo jo na Gozdarskem inštitutu Slovenije opravili leta 2011.

Tokratni anketni vprašalnik je bil razdeljen $\mathrm{v}$ dva sklopa: (1) rekrutacijski vprašalnik, na katerega so odgovarjala vsa gospodinjstva, ter (2) glavni vprašalnik, na katerega so odgovarjala samo gospodinjstva, ki imajo v lasti gozd. Rekrutacijski vprašalnik je vseboval skupno 8 vprašanj, in sicer o demografiji (spol, starost, socialni status), tipu in kraju prebivališča ter o lastništvu gozda ter gospodarjenju z njim. Glavni vprašalnik pa je obsegal 23 vprašanj, ki so se nanašala na osnovne informacije o gozdni posesti (površina, razdrobljenost), na značilnosti gospodarjenja z gozdom (namen in intenzivnost gospodarjenja, način prodaje lesa), na obseg in opravljanje sečnje in spravila lesa. Krajši del vprašanj se je nanašal na poškodbe gozdov zaradi ujm. Glavni vprašalnik je bil nadalje razdeljen na dva podsklopa, in sicer glede na to, kdo je opravljal delo v gozdovih (zasebni lastnik sam ali izvajalsko podjetje). Z odgovori smo zbrali nominalne in intervalne spremenljivke. Pri izbranih vprašanjih je bilo možnih več odgovorov, v večjem delu vprašanj pa je bilo možno podati le en odgovor.

Raziskava je potekala s pomočjo računalniško podprtega telefonskega anketiranja (CATI). Glede na način vzorčenja je osnovo vzorca predstavljal bruto vzorec, to so bila vsa gospodinjstva, ne glede na lastništvo goz- da, za katero se je zagotavljala reprezentativnost s kvotami po regiji in tipu naselja. Dodatno so bile postavljene tudi t.i. mehke kvote glede na starost anketirancev, $\mathrm{s}$ čimer je bilo zagotovljeno, da v vzorec niso bila zajeta zgolj starejša gospodinjstva, kar je pri telefonskih raziskavah precej običajno. Vzorec raziskave so predstavljala gospodinjstva, ki imajo v lasti gozd. Znotraj gospodinjstva je na vprašalnik odgovarjal lastnik gozda, ki z njim gospodari.

$\mathrm{V}$ anketi, namenjeni ugotavljanju stanja na področju opravljanja sečnje in spravila v zasebnih gozdovih v Sloveniji, je sodelovalo skupaj 2.883 gospodinjstev. Neto vzorec, torej gospodinjstva, ki imajo v lasti gozd in so hkrati bila pripravljena sodelovati pri telefonskem vprašalniku, je obsegal 544 gospodinjstev oz. lastnikov gozdov, od tega jih je 499 podalo vse odgovore, potrebne za opravljanje analiz.

$\mathrm{V}$ pridobljeni podatkovni bazi so bile $\mathrm{v}$ prvem koraku napravljene opisne statistike, vključno z razmerji med izbranimi spremenljivkami. Za potrditev zastavljenih hipotez so bile analizirane pomembne srednje vrednosti s statističnimi testi za parametrične ali neparametrične spremenljivke (odvisno od porazdelitve analiziranih podatkov). Značilne razlike med skupinami, zajetimi z raziskavo, smo preverili s Pearsonovim $\chi^{2}$ testom. Homogenost varianc smo preverili z Levenovim testom. Z neparametričnim Kruskal-Wallisovim testom smo preverili značilnost razlik med več različnimi kategorijami, medtem ko smo Welchev test uporabili za preverjanje razlik med dvema kategorijama. Statistična značilnost je določena na $5 \%$. Iz posameznih analiz smo izključili anketirance z manjkajočimi podatki.

\section{REZULTATI}

\section{RESULTS}

\subsection{Anketirani zasebni lastniki gozdov}

3.1 Surveyed private forest owners

Od 544 anketiranih zasebnih lastnikov gozdov je 60 \% moških, ki imajo v lasti 75 \% površin gozdov vseh anketiranih. Povprečna starost anketiranih lastnikov gozdov je bila 54 let. Glede na starost lastnikov zasebnih gozdov je s $44 \%$ prevladoval starostni razred od 46 do 60 let (slika 1), najmanj pa je mlajših lastnikov gozdov v starostnem razredu do 30 let.

Med anketiranimi lastniki gozdov je delež zaposlenih in samozaposlenih (46\%) ter delovno neaktivnih (45\%) skoraj povsem enak. Kmetijska gospodarstva pa zajemajo $9 \%$ vseh anketiranih zasebnih lastnikih gozda (slika 1).

Večji del zasebnih lastnikov gozdov prihaja iz ruralnih območij (66 \%). Največ anketiranih zasebnih lastnikov gozdov prihaja iz Osrednjeslovenske regije 


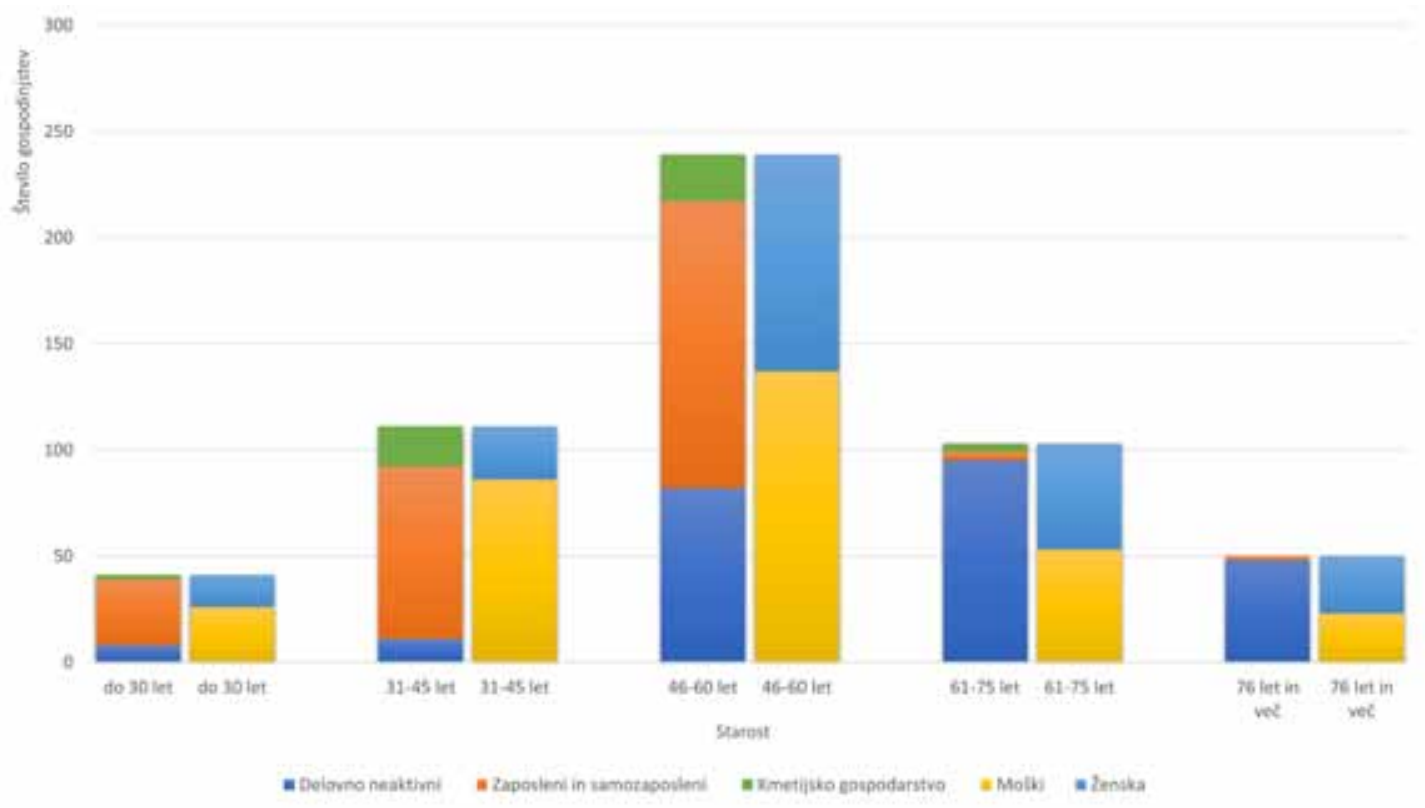

Slika 1: Starostna struktura in delovna aktivnost anketiranih zasebnih lastnikov gozdov

(20\%), s 14 \% sledita Podravska in Savinjska regija. Najmanj zasebnih lastnikov gozdov je bilo anketiranih iz Obalno-kraške regije (3\%), Koroške regije (3\%) in Zasavske regije (2\%).

\subsection{Gospodarjenje z zasebnimi gozdovi}

3.2 Management of private forests

Na drugi del vprašalnika, ki je bil namenjen izključno zasebnim lastnikom gozdov, je odgovorilo 544 anketirancev. Med njimi smo želeli ugotoviti, kdo in na kakšen način je v obdobju zadnjih petih let (2015-2019)
Fig. 1: Age structure and work activity of the surveyed private forest owners

gospodaril z gozdom oziroma opravil sečnjo in spravilo. Na vprašanje »Koliko hektarjev gozdov ima vaše gospodinjstvo v lasti ali solasti?« je odgovorilo 499 anketirancev, ki ima skupno v lasti ali solasti 3.133 ha gozda. Izmed 499 gospodinjstev jih ima $69 \%$ v lasti parcele velikosti do 4,99 ha. Po zadnjih podatkih Zavoda za gozdove Slovenije (2020) ima več kot 90 \% zasebnih lastnikov gozdov v Sloveniji posest manjšo kot 4,99 ha. Anketirana gospodinjstva, ki imajo $\mathrm{v}$ lasti gozdne posesti večje od 30 ha, zajemajo $4 \%$, medtem ko je takih lastnikov na ravni Slovenije zgolj 0,6 \% (ZGS, 2020). V primerjavi

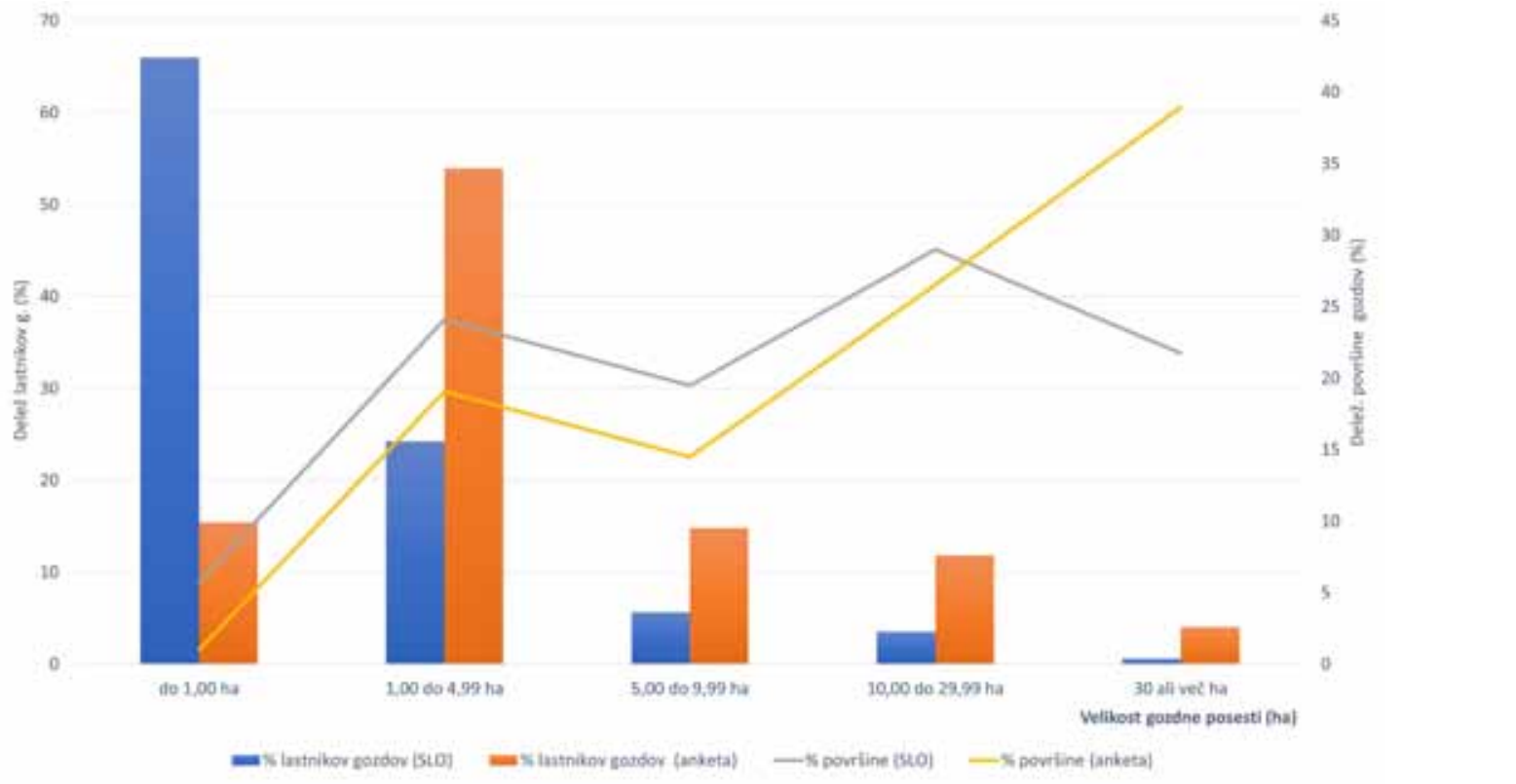

Slika 2: Primerjava med strukturo zasebnih lastnikov gozdov in površino gozdov po velikostnih kategorijah med anketiranimi in vsemi zasebnimi lastniki gozdov v Sloveniji (vir: anketa GIS ( $\mathrm{n}=499)$, ZGS 2020 za celotno Slovenijo)
Fig. 2: Comparison between the structure of forest owners and the forest area by size categories between respondents and all forest owners in Slovenia (Source: GIS survey ( $\mathrm{n}=$ 499), ZGS 2020 for Slovenia) 
s strukturo vseh zasebnih lastnikov gozdov v Sloveniji je bilo $v$ anketo vključenih manj zasebnih lastnikov gozdov z izrazito majhno posestvijo in večji delež lastnikov, ki ima posest veliko med 5 in 30 ha (slika 2).

Na vprašanje »Kakšen je vaš glavni namen gospodarjenja z gozdom?« je odgovarjalo 513 zasebnih lastnikov gozdov. Za $62 \%$ anketiranih je glavni namen gospodarjenja z gozdom uporaba lesa za lastne potrebe. S 23 \% sledijo zasebni lastniki, ki so gozd podedovali in nimajo posebnega namena gospodariti $\mathrm{z}$ njim. Le $6 \%$ vprašanih zasebnih lastnikov gospodari z gozdom z namenom trženja lastnega lesa in/ali drugih gozdnih proizvodov. Pri prodaji lesa prevladuje odkup na kamionski cesti (71\%), kar $29 \%$ pa predstavlja odkup na panju. Več kot $66 \%$ anketiranih je izjavilo, da les ne prodaja. Med slednjimi prevladujejo tisti, ki so navedli, da je glavni namen gospodarjenja zagotavljanje lesa za lastne potrebe (70 \%) oziroma, da so gozd podedovali in nimajo posebnega namene gospodarjenja (11\%), nihče med njimi pa ni navedel, da je glavni namen gospodarjenja prodaja lesa.

Povezavo med namenom gospodarjenja z gozdom ter spolno strukturo zasebnih lastnikov gozda smo testirali s Pearsonovim $\chi^{2}$-testom neodvisnosti. Število pričakovanih frekvenc je večje od $5 \mathrm{v}$ vseh kategorijah odgovorov. $S$ tem so izpolnjeni pogoji za $\chi^{2}$-test. Slika 3 prikazuje, da med spolom in načinom gospodarjenja obstajajo statistično značilne razlike $\left(\chi^{2}=22,954\right.$, df $=$
$4, p<0,001)$. Na podlagi analize Pearsonovih ostankov ugotavljamo, da je število moških lastnikov značilno večje od pričakovanih vrednosti in ženskih lastnic značilno nižje od pričakovanih vrednosti v skupini lastnikov, ki so za glavni namen gospodarjenja izbrali odgovor »finančna rezerva«. Enako se odkloni od pričakovanih vrednosti kažejo v skupini lastnikov, ki nimajo posebnih namenov gospodarjenja z gozdom.

Na vprašanje »Ali se je v vašem gozdu v obdobju zadnjih 5 let opravljala sečnja oz. spravilo lesa?« so odgovarjali lastniki gozdov, ki gospodarijo z lastnim gozdom ( $n=513$ ). 365 zasebnih lastnikov oz. $71 \%$ od vprašanih jih je v obdobju 2015-2019 opravljalo sečnjo in spravilo lesa. Zasebni lastniki, ki so v obdobju 2015-2019 opravljali sečnjo in spravilo lesa v lastnih gozdovih in so navedli količine poseka ter hkrati tudi površino gozda ( $\mathrm{n}=353$ ), so v tem času skupaj posekali $49.965 \mathrm{~m}^{3}$ lesa, kar pomeni v povprečju $24 \mathrm{~m}^{3}$ /ha (standarni odklon ali $\mathrm{SD}=35 \mathrm{~m}^{3} / \mathrm{ha}$ ) ter $141 \mathrm{~m}^{3}$ na gospodinjstvo. Absolutno gledano so največ količin posekali zasebni lastniki z velikimi gozdnimi posestmi (nad 30 ha), in sicer 24.790 $\mathrm{m}^{3}$. Največja intenziteta sečnje pa je bila pri zasebnih lastnikih z malimi gozdnimi posestmi (do 0,99 ha), in sicer je znašala $v$ povprečju $41,4 \mathrm{~m}^{3} /$ ha s standardnim odklonom 49,3 $\mathrm{m}^{3}$ /ha (slika 4). Najmanj intenzivno so v zadnjih petih letih opravljali sečnjo lastniki gozdov, ki imajo v lasti med 10 in 29,99 ha gozda, ti so v povprečju sekali $11,5 \mathrm{~m}^{3} /$ ha s standardnim odklonom $14 \mathrm{~m}^{3} /$

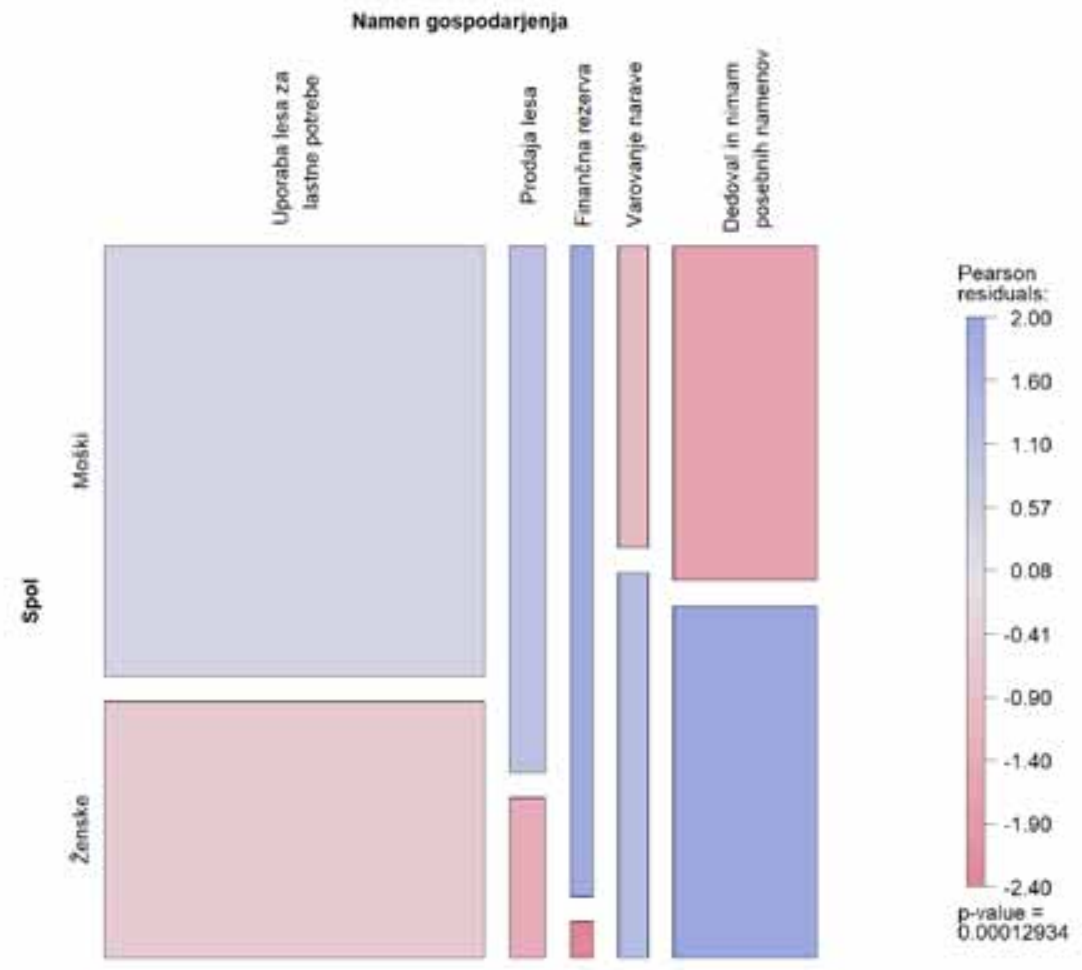

Slika 3: Struktura zasebnih lastnikov gozdov glede na spol in

Fig. 3: Structure of private forest owners according to gender namen gospodarjenja 


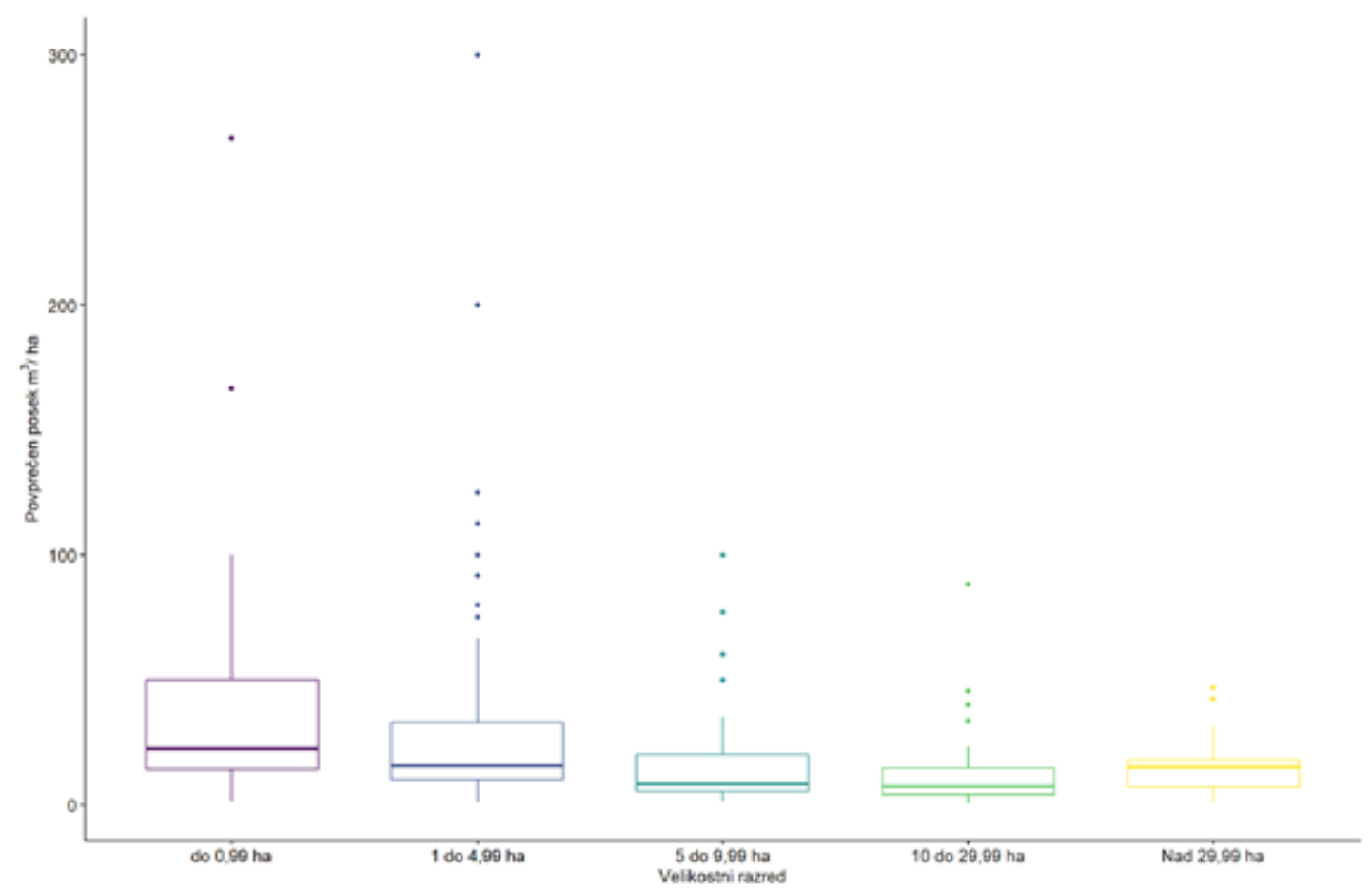

Slika 4: Količina posekanega lesa $\left(\mathrm{m}^{3} / \mathrm{ha}\right) \mathrm{v}$ petih letih po velikostnih kategorijah $(\mathrm{n}=353)$

ha. Neparametrični Kruskal-Wallisov test je pokazal, da obstajajo statistično značilne razlike v količini opravljene sečnje v zadnjih 5 letih med različnimi kategorijami velikosti gozdne posesti $\left(\chi^{2}=43,603, p<0,001\right) \mathrm{z}$ intenziteto sečnje (slika 4). Statistično analizo smo nadaljevali s testom mnogoterih primerjav (Dunnov test $\mathrm{z}$ Bonferronijevo korekcijo), ki je zasebne lastnike uvrstil
Fig. 4: The amount of harvested wood $\left(\mathrm{m}^{3} / \mathrm{ha}\right)$ in five years by size categories in this period $(n=353)$

v dve skupini. V skupini 1 so lastniki s skupno površino posesti do 0,99 ha, 1 do 4,99 ha in nad 29,99 ha, v skupini 2 pa lastniki s skupno površino posesti 5-9,99 ha, 10 do 29,99 ha in nad 29,99 ha.

Podatke o količini poseka ter površini gozdne posesti je posredovalo 230 moških in 123 žensk. Moški lastniki so $\mathrm{v}$ obravnavanem obdobju posekali $85 \%$

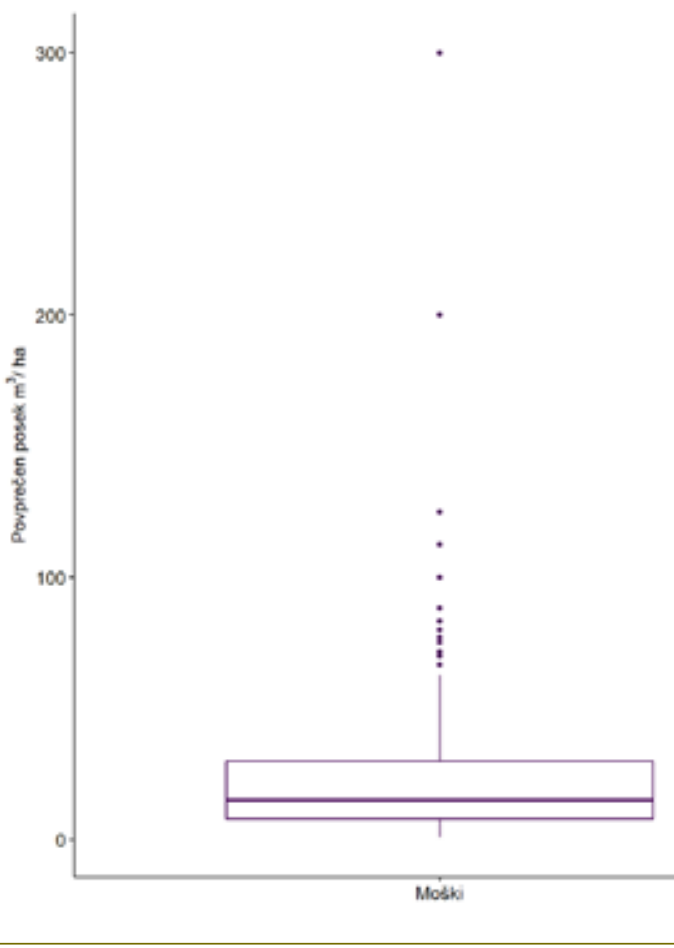

Slika 5: Količina posekanega lesa $\left(\mathrm{m}^{3} / \mathrm{ha}\right) \mathrm{v}$ petih letih po spolu $(\mathrm{n}=361)$
Fig. 5: The amount of harvested wood $\left(\mathrm{m}^{3} / \mathrm{ha}\right)$ in five years by forest owner gender $(n=361)$ 
skupne količine posekanega lesa. Povprečna količina posekanega lesa ženske skupine je znašala $22,5 \mathrm{~m}^{3} / \mathrm{ha}$ $(\mathrm{SD}=34,4)$, medtem ko je bila povprečna količina posekanega lesa moške skupine $25,4 \mathrm{~m}^{3}$ /ha ( $\mathrm{SD}=36,3$ ) (slika 5). Welchev test a z dvema vzorcema je pokazal, da razlika med dvema vzorcema ni statistično značilna $(p>0,05, \mathrm{t}=-0,749, \mathrm{df}=261,42)$.

\subsection{Opravljanje sečnje in spravila v zasebnih gozdovih}

3.3 Implementation of felling and skidding in private forest

Pri vseh anketirancih, ne glede na velikost posesti, prevladujeta lastno opravljeni sečnja in spravilo lesa v gozdovih oziroma so to delo lastniki opravili s pomočjo družinskih članov (slika 6). Najvišji delež sečnje in spravila, ki ga opravijo zasebni lastniki sami oziroma s pomočjo družinskih članov, je v najmanjših kategorijah zasebnih lastnikov gozdov (do 5 ha), kjer je ta delež več kot 75 \%. Z nekoliko manjšim deležem (73 \%) sledi velikostna kategorija 10-29,99 ha.

Zasebnim lastnikom, ki so navedli, da so delo v gozdu opravljali sami oziroma s pomočjo družinskih članov, smo namenili v anketi poseben sklop vprašanj, s

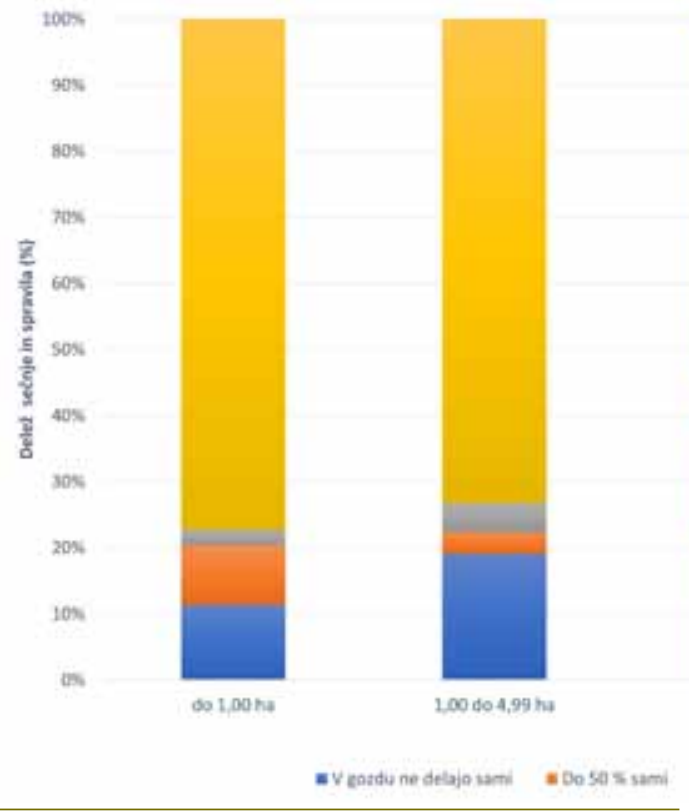

Slika 6: Delež sečnje in spravila, ki ga anketirani opravijo sami oziroma z družinskimi člani

Preglednica 1: Število in starost oseb, ki so opravljale posek in spravilo lesa v lastnem gozdu katerimi smo želeli ugotoviti nekaj dodatnih značilnosti opravljanja del v gozdovih. Od 365 zasebnih lastnikov, ki so v omenjenem obdobju aktivno gospodarili z gozdom, jih je 317 (oz. 87 \%) takšnih, ki so posek in spravilo vsaj delno opravili sami oz. z družinskimi člani. Znotraj enega gospodinjstva je delo v gozdu opravljalo do 6 oseb (ti so v preglednici 1 vključeni v razred 4 osebe ali več). V največ primerih sta bili pri delu v gozdu prisotni dve ali tri osebe (preglednica 1).

Člani gospodinjstva, ki opravljajo delo v gozdu, so se sečnje in spravila največkrat (37 \%) naučili iz lastnih izkušenj (slika 7). Z 28 \% sledi prenos znanja prek poznanstev, šele na tretjem mestu z $20 \%$ pa so znanje pridobili $s$ pomočjo strokovnih tečajev za sečnjo in spravilo lesa. Anketa je med člani gospodinjstev zajela $5 \%$ takšnih, ki imajo opravljeno nacionalno poklicno kvalifikacijo.

Večina manjših zasebnih lastnikov gozdov (skoraj 70 \%) se uči dela v gozdu iz lastnih izkušenj in s prenosom znanja (slika 7). Za opravljanje tečajev se najbolj odločajo lastniki gozdov z velikostjo posesti 10-29,99 ha, največji lastniki gozdov (nad 30 ha posesti) pa so se v $30 \%$ naučili opravljati sečnjo in spravilo lesa iz lastnih izkušenj. $20 \%$ od anketiranih največjih zasebnih lastnikov je znanje pridobilo na tečajih za sečnjo in spravilo lesa.

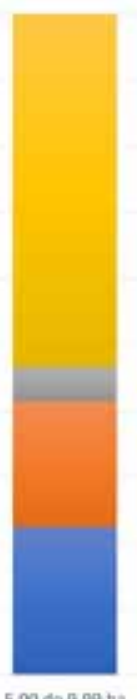

$5,00609,99$ ha

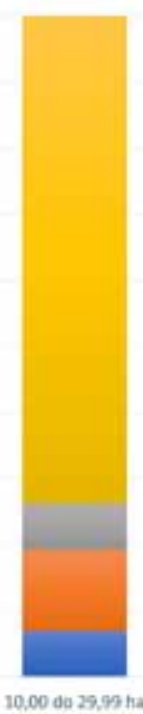

$10,00 \mathrm{do} 29,99 \mathrm{~h}$

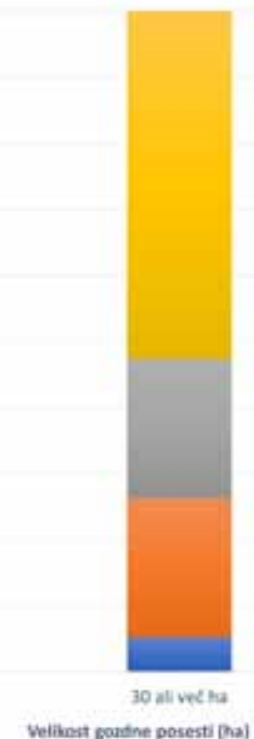

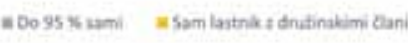

Fig. 6: Proportion of harvesting and skidding carried out by the respondents themselves or with family members

Table 1: Number and age of persons who harvested wood in their own forest

\begin{tabular}{|c|c|c|c|}
\hline Število oseb & Število gospodinjstev & Minimalna starost & Maksimalna starost \\
\hline 1 & 40 & 18 & 88 \\
\hline 2 & 130 & 13 & 86 \\
\hline 3 & 101 & 14 & 83 \\
\hline 4 ali več & 46 & 15 & 74 \\
\hline
\end{tabular}


Na vprašanje, ali pri delu v gozdu uporabljajo osebno varovalno opremo, jih je kar $96 \%$ odgovorilo pritrdilno. Kar zadeva varovalno opremo za sečnjo in spravilo lesa, največ zasebnih lastnikov (97\%) uporablja zaščitne rokavice. Z 91 $\%$ sledi uporaba čelade ter z $82 \%$ uporaba protivreznih hlač. Najmanj, vendar še vedno skoraj 70 \%, uporablja glušnike. V sklopu opravljanja dela v gozdu nas je pri anketirancih še zanimalo, s katerimi delovnimi stroji, ki so v njihovi lasti, opravljajo sečnjo in spravilo lesa. Na vprašanje je odgovorilo 317 anketiranih, ki v največ primerih uporabljajo lastno motorno žago (97\%). Temu pa z 61 \% sledi uporaba kmetijskega traktorja z vitlom. Med ponujenimi odgovori sta bila najmanjkrat izbrana goseničar (1\%) in gozdarska žičnica (1 \%). Pod drugo (3\%) pa so anketirani navedli cepilni stroj, sekiro, avtomobilsko prikolico in cepin.

Večina anketiranih lastnikov gozdov (75 \%), ki je v zadnjih petih letih sekala, je sečnjo in spravilo opravila sama brez najetih izvajalcev del, $15 \%$ je dela opravila izključno z najetimi izvajalci del, nadaljnjih $6 \%$ je polovico del opravila s pomočjo najetih izvajalcev del, $4 \%$ pa je $95 \%$ sečnje in spravila opravila s pomočjo gozdarskega podjetja (slika 8). V skupini zasebnih lastnikov, ki imajo v lasti med 5 in 9,99 ha gozda, je največji delež tistih, ki so vso sečnjo in spravilo opravili izključno z najetimi gozdarskimi storitvami (22\%). Med njimi z 68 \% prevladujejo ženske lastnice ter z $62 \%$ delovno neaktivni zasebni lastniki. Najnižji delež (7 \%) najemanja gozdarskih storitev za sečnjo in spravilo je pri anketiranih, ki imajo od 10 do 29,99 ha gozda. Med največjimi lastniki gozdov jih 37 \% najema izvajalce za sečnjo in spravilo, a jih $11 \%$ med njimi celotno izvedbo sečnje in spravila zaupa gozdarskim podjetjem.
Vpliv velikosti gozdnega posestnika na najemanje gozdarskih storitev je bil testiran s statističnim testom $\chi^{2}$-test. Slika 9 prikazuje, da med velikostjo posesti in načinom izvedbe sečnje in spravila obstajajo statistično značilne razlike $\left(\chi^{2}=13,195, \mathrm{df}=2, p<0,05\right)$. Nadaljujemo s testom parnih primerjav. Na podlagi analize Pearsonovih ostankov kaže, da je število zasebnih lastnikov, ki so sečnjo in spravilo opravljali samostojno in $\mathrm{z}$ najetimi izvajalci, značilno večje od pričakovanih vrednosti v skupini večjih lastnikov (velikost posesti nad 4,99 ha). Pozitivna asociacija se pokaže tudi v skupini manjših zasebnih lastnikov, ki so sečnjo in spravilo v celoti opravili samostojno brez pomoči najetih izvajalcev.

Zasebni lastniki gozdov, ki so najeli izvajalsko podjetje ali strojni krožek, so odgovarjali še na poseben sklop vprašanj. Od 365 zasebnih lastnikov, ki so v omenjenem obdobju aktivno gospodarili z gozdom, jih je 98 (oz. 27 \%) takšnih, ki so za opravljanje sečnje in spravila najeli profesionalne gozdarske delavce.

Kot glavni razlog za najem izvajalca za delo v lastnem gozdu so zasebni lastniki navedli zahtevnost dela (30\%), sledi pomanjkanje ustrezne delovne in osebne varovalne opreme (24\%) in, kot tretje, da je delo tako bolj učinkovito in kvalitetno opravljeno (16 \%). Pri izbiri izvajalca del za sečnjo in spravilo je zasebnim lastnikom najbolj (kar v 44 \%) pomembna kakovost izvedbe del, čemur tudi v dokaj visokem deležu (37 \%) sledi poštenost. Najmanj sodelujočih je izbralo odgovor drugo (5\%), pri čemer so dodatno zapisali, da jim je pomembna bližina in poznanstvo z izvajalcem del. Kljub temu, da je le majhen delež zasebnih lastni-

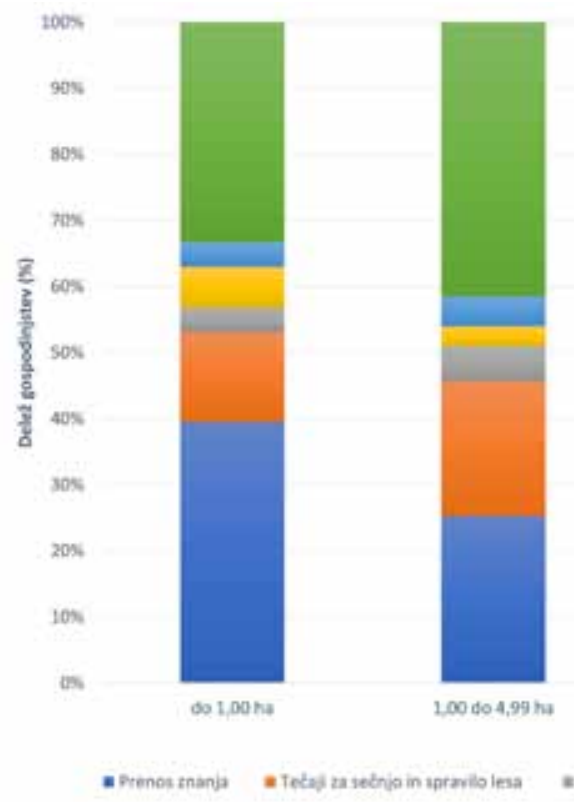

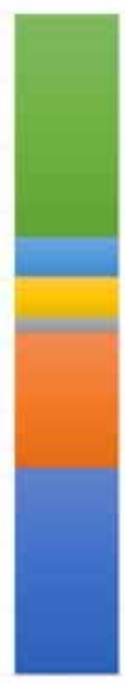

$5,00609,99$ ha

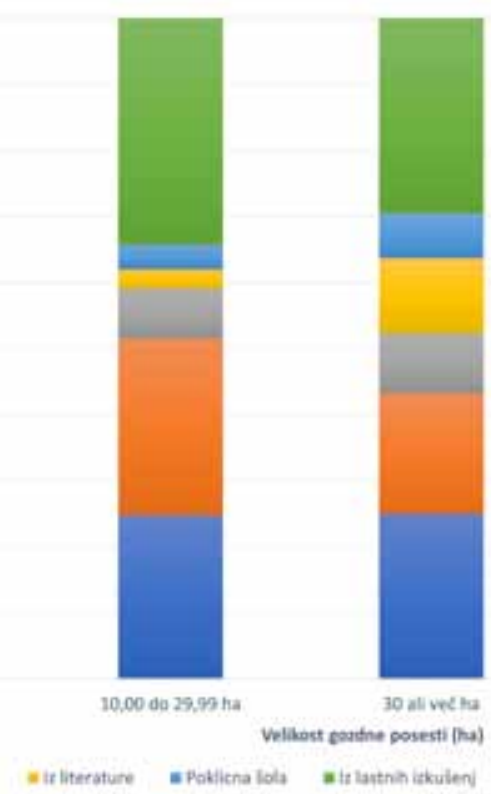

Slika 7: Načini učenja opravljanja poseka in spravila glede na velikostni razred gozdne posesti, ki je v lasti posameznega anketiranega zasebnega lastnika
Fig. 7: Ways of learning how to carry out harvesting according to the size class of the forest estate owned by each surveyed private forest owner 


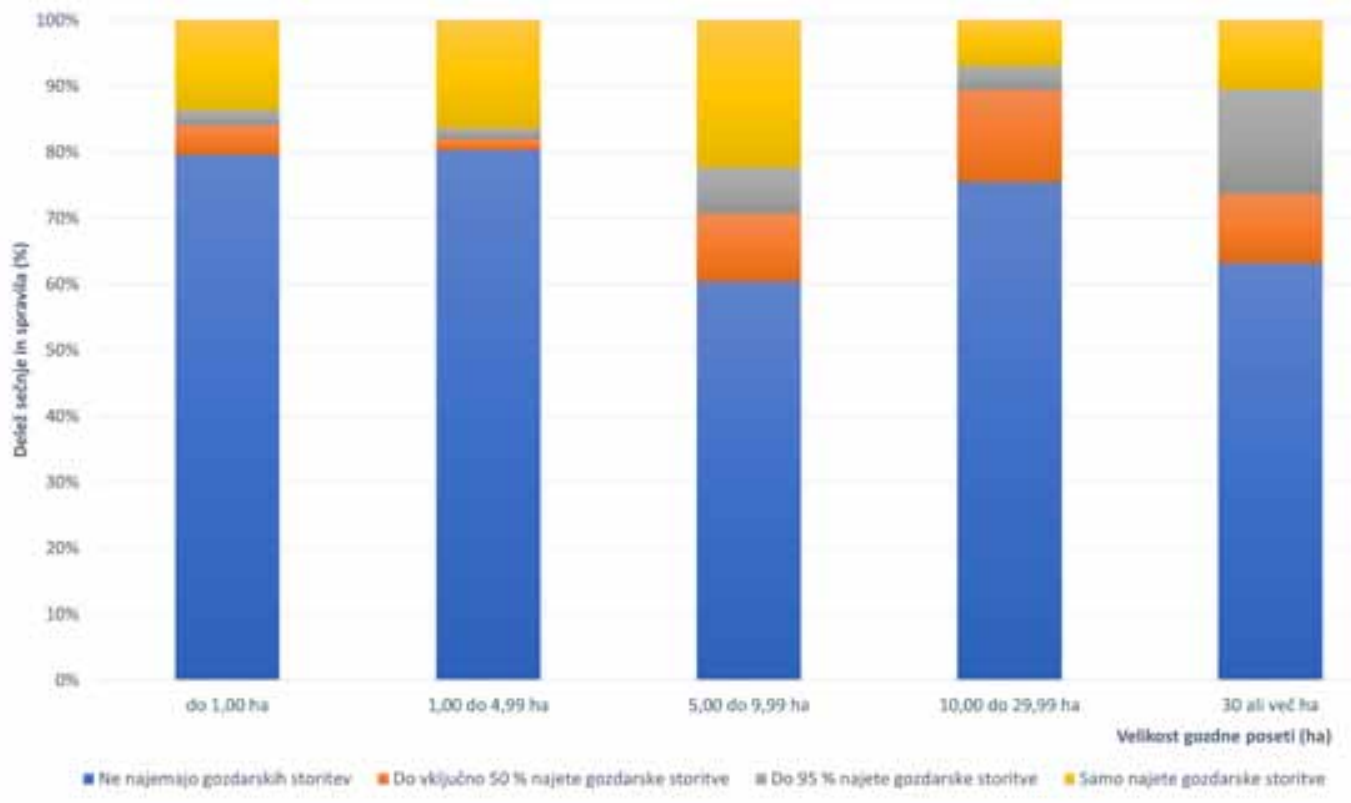

Slika 8: Delež sečnje in spravila, za katerega anketirani najamejo gozdarsko podjetje oziroma zunanjega izvajalca

kov navedlo, da jim je pri izbiri izvajalca pomembno poznanstvo, velik delež (53\%) le teh poišče in izbere izvajalca, ki opravlja sečnjo in spravilo v njihovem gozdu, na podlagi poznanstva in sorodstva. Z $29 \%$ sledi izbor izvajalca po priporočilih. $V$ enem primeru zasebnemu lastniku ni bilo treba iskati izvajalca, saj je ta sam dal ponudbo za izvedbo del, zgolj dva pa sta navedla, da sta poiskala izvajalca prek spleta.
Fig. 8: Proportion of harvesting for which the respondents hired a forestry company or an external contractor

\subsection{Gospodarjenje z zasebnimi gozdovi v priho- dnosti}

3.4 Private forest management in the future

Na vprašanje »Kako nameravate gospodariti $\mathrm{z}$ vašim gozdom v prihodnje?« so zasebni lastniki gozdov, ne glede na velikost gozdne posesti, $v$ večini mnenja, da bodo $\mathrm{v}$ prihodnje $\mathrm{z}$ lastnimi gozdovi gospodarili enako kot doslej (slika 10). Naslednji največkrat izbrani od-

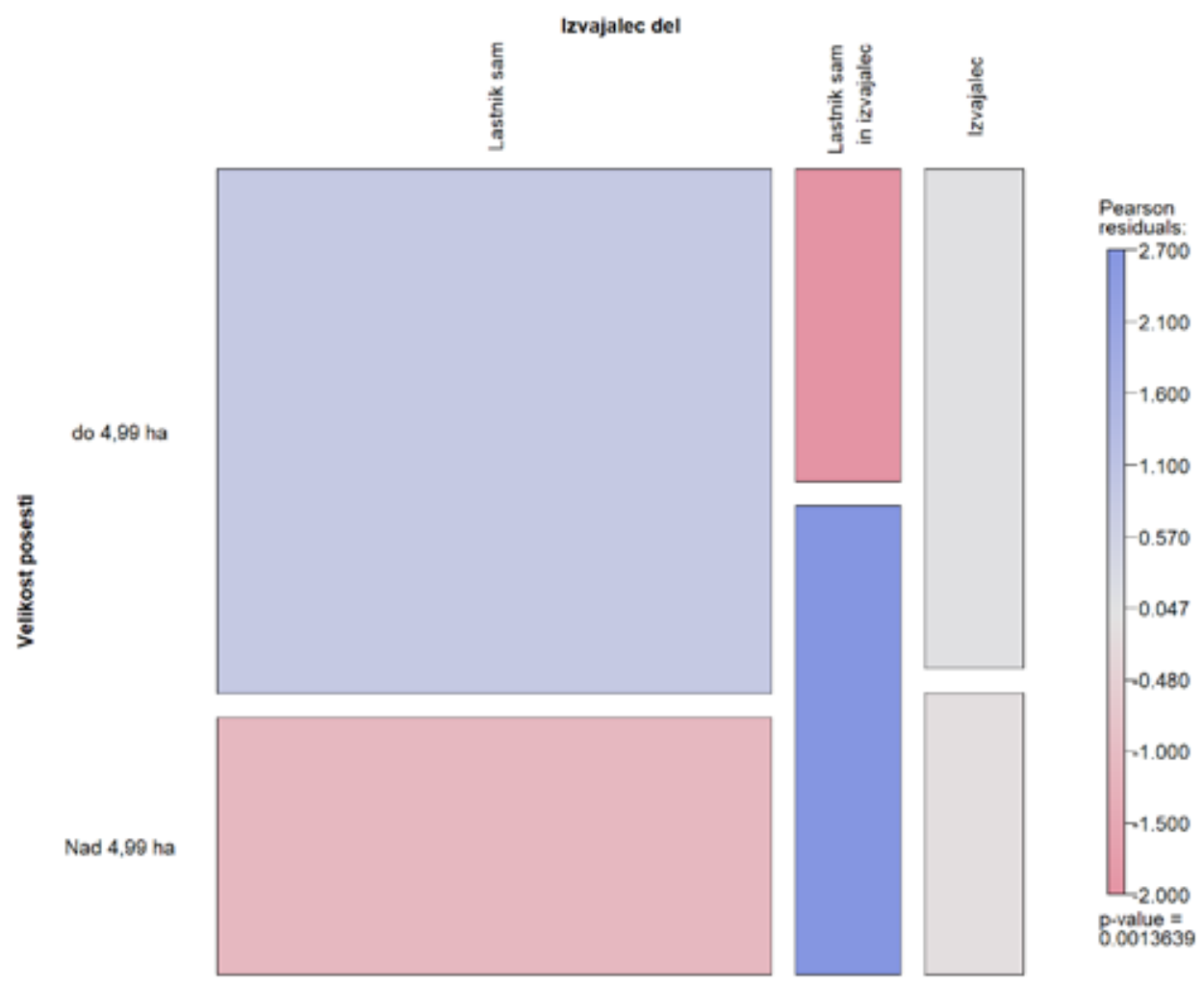

Slika 9: Struktura zasebnih lastnikov gozdov glede na velikost posesti in način opravljanja sečnje in spravila
Fig. 9: Structure of private forest owners according to the size of the property and the method of harvesting 


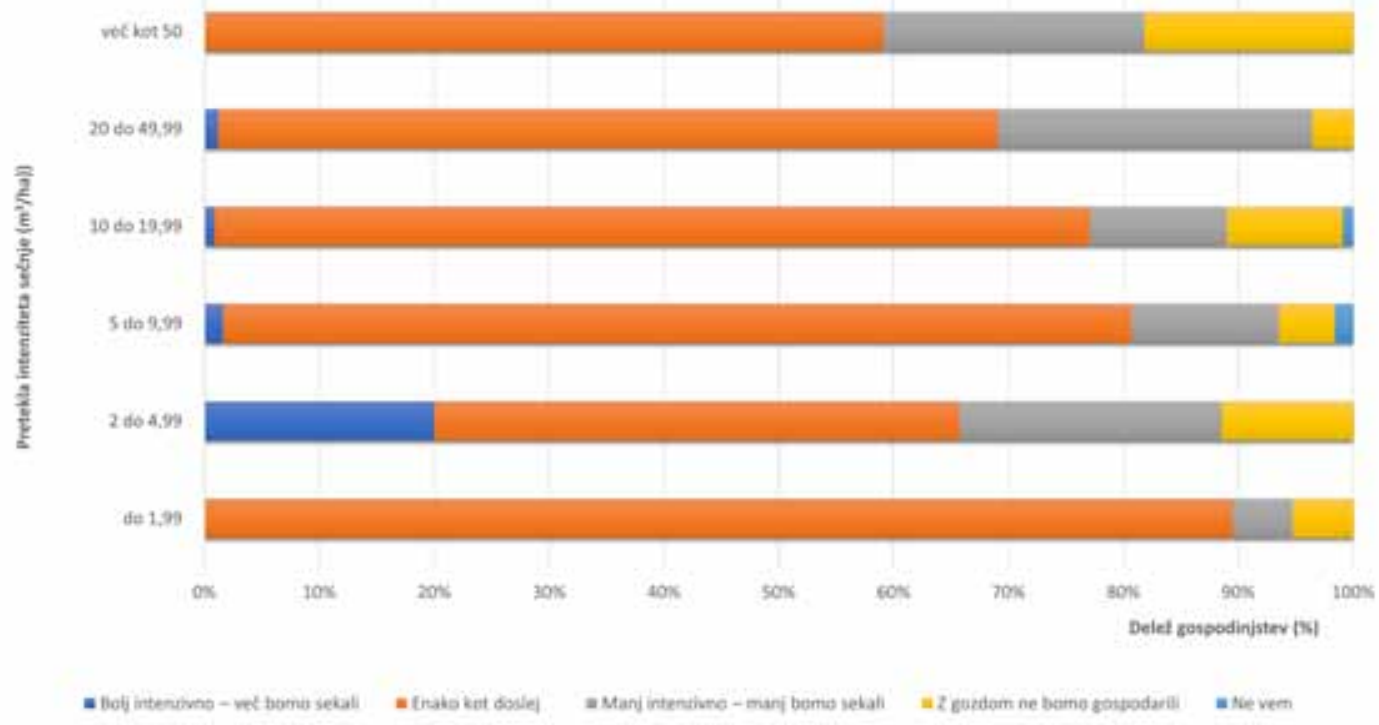

Slika 10: Predvidena intenzivnost gospodarjenja z gozdovi glede na količino poseka v lastnih gozdovih v obdobju 2015$2019\left(\mathrm{v} \mathrm{m}^{3} / \mathrm{ha}\right)$

govor je bil manj intenzivno, predvsem pri zasebnih lastnikih, ki so v zadnjih petih letih posekali $20 \mathrm{~m}^{3} / \mathrm{ha}$ ali več. Med zasebnimi lastniki, ki so odgovarjali na to vprašanje, sledijo tisti, ki v prihodnje ne nameravajo gospodariti z gozdom. Le $3 \%$ zasebnih lastnikov pa je bilo mnenja, da bodo v prihodnje $\mathrm{z}$ gozdom bolj intenzivno gospodarili. Med njimi prevladujejo lastniki, ki so v obdobju 2015-2019 posekali od 2 do 4,99 $\mathrm{m}^{3}$ lesa na hektar. Med zasebnimi lastniki gozdov, ki so v zadnjih petih letih posekali $5 \mathrm{~m}^{3}$ /ha ali več, jih le $1 \%$ razmišlja o bolj intenzivnem gospodarjenju.
Fig. 10: Predicted intensity of forest management according to the amount of wood harvested in the owner's forests in the period 2015-2019 (in $\left.\mathrm{m}^{3} / \mathrm{ha}\right)$

Glede razmišljanja oz. videnja, kako bodo gospodarili z lastnim gozdom $\mathrm{v}$ prihodnosti, ni značilnih razlik med spoloma $(p>0,05)$, kar kaže tudi spodnji grafikon (slika 11).

\section{RAZPRAVA}

4 DISCUSSION

$\mathrm{V}$ raziskavi, v kateri je bilo zajetih 544 naključno izbranih zasebnih lastnikov gozdov, so z več kot $50 \%$ prevladovali lastniki z velikostjo gozdne posesti od 1 do 4,99 ha. Ta delež je precej večji kot v nacionalni strukturi
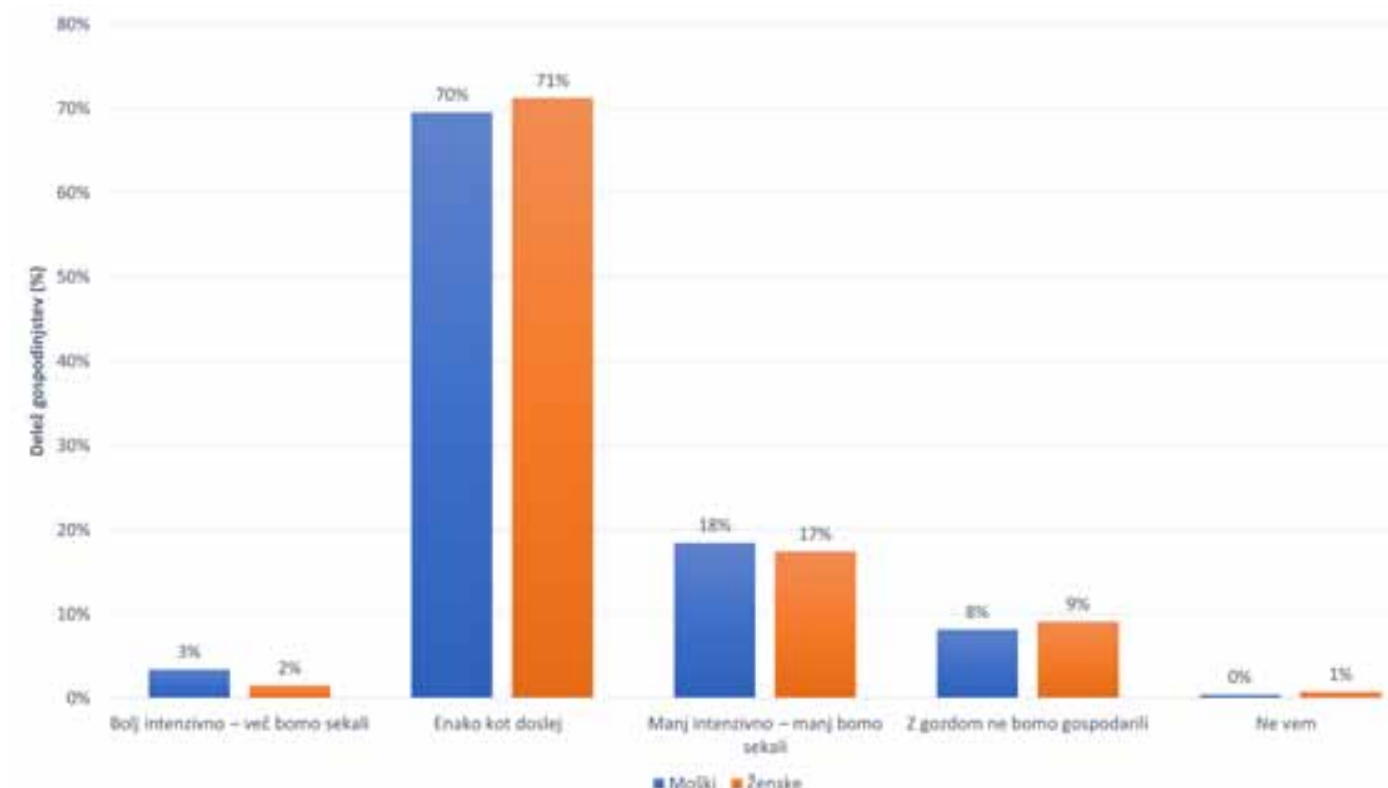

Slika 11: Predvideno gospodarjenje z gozdovi v prihodnosti glede na spol zasebnega lastnika gozda

Fig. 11: Expected forest management in the future according to the gender of the private forest owner 
zasebnih lastnikov, kjer pa (z 67 \%) prevladujejo zasebni lastniki z gozdno posestvijo velikosti do 1 ha. Med anketiranimi zasebnimi lastniki gozda je $71 \%$ takšnih, ki so v obdobju zadnjih petih let (2015-2019) opravili sečnjo in spravilo lesa. Skupaj so posekali nekaj manj kot 50.000 $\mathrm{m}^{3}$ lesa (oz. povprečno $24 \mathrm{~m}^{3} / \mathrm{ha}$ ), ki v $67 \%$ ne gre na trg, ampak se porabi večinoma (84 \%) za pokrivanje lastnih potreb. Zasebni lastniki, ki sami opravljajo sečnjo in spravilo v gozdu ali pa s pomočjo družinskih članov, imajo pri delu navzočih največkrat dve ali tri osebe različnih starostnih skupin. Rezultati o številu in starosti oseb kažejo na medgeneracijsko sodelovanje pri delu v gozdu, kjer delajo tako mlajše kot starejše osebe. Člani gospodinjstev, ki sami delajo v gozdu, so se dela največkrat priučili iz lastnih izkušenj in so hkrati v $96 \%$ opremljeni z osebno varovalno opremo. Pri opravljanju sečnje in spravila jih 97 \% uporablja lastno motorno žago, $61 \%$ jih uporablja kmetijski traktor $\mathrm{z}$ vitlom.

$Z$ raziskavo smo potrdili, da velikost zasebne gozdne posesti vpliva na intenziteto sečnje in spravila, torej lahko potrdimo prvo zastavljeno hipotezo. Velikost gozdne posesti je ena izmed najbolj pogostih uporabljenih spremenljivk v študijah pridobivanja lesa v zasebnih gozdovih in večina študij je potrdila pozitiven učinek velikosti gozdne posesti na zanimanje in intenzivnost opravljanje sečnje in spravila (npr. Beach in sod. 2005; Molnar in sod. 2007, Eggers in sod. 2014, Poje in sod. 2016). Tudi najnovejše študije (Bashir in sod., 2020) potrjujejo pozitivno povezavo med velikostjo gozdnih posesti in namero zasebnih lastnikov gozdov o poseku lesa, kot tudi, da za manjše zasebne lastnike gozdov njihove gozdne posesti nimajo pomembne gospodarske funkcije in so manj pripravljeni za gospodarjenje (Juutinen in sod., 2020). Raziskava med zasebnimi lastniki gozdov v Franciji (Petucco in sod., 2015) pa je pokazala, da manjši zasebni lastniki gozdov sekajo manj pogosto, vendar bolj intenzivno, da bi zmanjšali povprečne stroške sečnje.

Glede na odgovore anketiranih, ki so v obdobju 2015-2019 za izvedbo sečnje in spravila najeli gozdarska podjetja, ugotavljamo, da so ta podjetja v zadnjih petih letih posekala več kot $20.000 \mathrm{~m}^{3}$ lesa oziroma lahko ocenimo, da so pri zasebnih lastnikih gozda, ki so v obdobju 2015-2019 opravljali sečnjo in spravilo, kar $41 \%$ poseka opravili poklicni izvajalci del. Ocena poseka, ki so ga opravili najeti izvajalci del, je narejena na podlagi podatkov o poseku lesa in deležu izvedenega poseka s strani najetih izvajalcev gozdarskih del. Anketiranci so namreč podali oceno, koliko sečnje in spravila opravijo sami (in s pomočjo družinskih članov), in koliko z najetimi izvajalci gozdarskih del. Kot glavni razlog za najem izvajalca za sečnjo in spravilo je bila navedena zahtevnost dela, pri izbiri izvajalca za sečnjo in spravilo pa se je zasebnim lastnikom gozda zdela najbolj pomembna kakovost izvedbe del v gozdu. $V$ tujih raziskavah je bilo že večkrat ugotovljeno, da se med zasebnimi lastniki gozdov zmanjšuje delež tistih, ki vsa dela opravijo sami oziroma s pomočjo družinskih članov, in povečuje delež najetih izvajalcev del (Westermayer, 2006; Andersson in H. Keskitalo, 2019). $\mathrm{Z}$ raziskavo smo ugotovili, da med velikostjo zasebne gozdne posesti in načinom izvedbe sečnje in spravila obstajajo statistično značilne razlike. V skupini zasebnih lastnikov, ki si lastijo površino do 4,99 ha ter sečnjo in spravilo opravljajo samostojno brez pomoči najetih izvajalcev, so dejanske vrednosti frekvenc značilno različne od pričakovanih vrednosti. Enako velja za skupino lastnikov gozdov, ki imajo v lasti površino, večjo od 5 ha, in sečnjo ter spravilo opravijo delno samostojno in delno s pomočjo najetih izvajalcev. Večji lastniki, z gozdno posestvijo velikosti 30 ha ali več, so za sečnjo in spravilo v $37 \%$ najeli izvajalca del, od tega jih je 11 $\%$, ki so celotno sečnjo in spravilo zaupali gozdarskim podjetjem. Največji delež tistih zasebnih lastnikov, ki vsa dela opravijo s pomočjo najetih izvajalcev, je v velikostnem razredu gozdne posesti od 5 do 9,99 ha (22\% anketiranih $\mathrm{v}$ tem velikostnem razredu). $\mathrm{Z}$ zgoraj navedenim lahko potrdimo tudi drugo zastavljeno hipotezo.

Pezdevšek Malovrh in sodelavci (2010) so ugotovili, da so večji lastniki gozdov, z gozdno posestvijo velikosti 30 ha ali več, bolj naklonjeni povezovanju z drugimi lastniki gozdov za učinkovitejše gospodarjenje z gozdom. Da večji lastniki gozdov večkrat najamejo zunanje izvajalce del, potrjuje tudi raziskava na Portugalskem (Novais in Canadas, 2010), kjer so ugotovili, da izvajalce del večkrat najamejo lastniki srednje velikih, velikih in največjih gozdnih posesti. Dostikrat je ta značilnost tudi povezana z oddaljenostjo gozda do kraja bivanja in spolom lastnika gozda. Ugotovili so namreč, da ženske lastnice večjih gozdnih posesti, kot tudi lastniki, ki ne živijo na svoji gozdni posesti, večkrat najamejo izvajalce gozdarskih storitev. Novejše študije še ugotavljajo, da vse večja heterogenost zasebnih lastnikov gozdov (npr. spremembe zaradi urbanizacije in višje stopnje izobrazbe zasebnih lastnikov gozdov) povečuje potrebe zasebnih lastnikov gozdov po izvajalcih del ter po bolj celostnih in dovršenih storitvah (Mattila in Roos, 2014; Häyrinen in sod., 2015; Erlandsson, 2016).

$\mathrm{V}$ anketi je sodelovalo več moških lastnikov gozdov kot ženskih. Rezultati ankete kažejo, da so moški zasebni lastniki gozda posekali kar 85 \% od celotne količine poseka v obdobju 2015-2019. Vendar kljub temu ni večjih razlik glede na intenziteto sečnje, saj so moški lastniki v povprečju posekali $25,4 \mathrm{~m}^{3}$ /ha lesa, ženske lastnice pa $22,4 \mathrm{~m}^{3}$ /ha. Na podlagi vzorca zasebnih lastnikov goz- 
dov, vključenih $\mathrm{v}$ raziskavo, nismo potrdili statistično značilnih razlik $v$ intenziteti poseka med spoloma. Posledično smo tretjo zastavljeno hipotezo ovrgli. Glede na spol zasebnega lastnika gozda pa smo z raziskavo potrdili statistično značilne razlike glede na glavni namen gospodarjenja z lastnim gozdom. Pri obeh spolih sicer prevladuje uporaba lesa za lastne potrebe, s študijo pa smo potrdili, da je več ženskih lastnic, ki so gozd podedovale in nimajo posebnega namena gospodarjenja z njim ali pa je glavni namen gospodarjenja varstvo narave. 35 $\%$ ženskih lastnic gozda v zadnjih petih letih ni opravljalo poseka v lastnem gozdu, medtem ko je ta delež pri moških nižji (25\%). Glede na rezultate raziskave $76 \%$ ženskih lastnic gozda ne prodaja lesa na trgu, medtem ko je delež pri moških nižji in znaša $62 \%$. Študija na Finskem je pokazala, da so ženske lastnice posekale kar 30 \% manj lesa kot moški (Kuuluvainen in sod., 2014). Prav tako novejša študija na Norveškem potrjuje, da moški lastniki gozdov posekajo več kot ženske (Bashir in sod., 2020). Študija med zasebnimi lastniki gozdov na Švedskem pa je pokazala, da imajo ženske lastnice močnejši odnos do ekoloških in rekreacijskih funkcij gozda ter okoljskih vidikov gospodarjenja z gozdovi, vendar kljub temu niso ugotovili večjih razlik med spoloma v povezavi z gozdnimi vrednotami ter namenom gospodarjenja $\mathrm{z}$ gozdovi (Nordlund in Westin, 2011).

\section{ZAKLJUČKI}

\section{CONCLUSIONS}

Ugotovili smo, da velikost zasebne gozdne posesti vpliva na intenziteto sečnje in spravila v zasebnih gozdovih, in sicer je bila intenziteta sečnje največja pri malih zasebnih lastnikih (do 0,99 ha), najmanjša pa pri zasebnih lastnikih z gozdno posestvijo v velikosti med 10 in 29,99 ha. Vendar manjši zasebni lastniki sečnjo opravljajo predvsem z namenom pokrivanja lastnih potreb (npr. za ogrevanje gospodinjstev) in nimajo izrazite vloge na trgu lesa.

Nekaj manj kot polovico poseka in spravila so lastniki opravili s pomočjo najetih izvajalcev gozdarskih del. Večji zasebni lastniki gozdov pogosteje najemajo gozdarske storitve kot manjši zasebni lastniki gozdov. Kot glavni razlog za najem gozdarskega izvajalca je zahtevnost dela, pri izbiri izvajalca gozdarskih del pa je najpomembnejša kakovost izvedbe. V nadaljevanju bo smiselno pripraviti dodatne analize vpliva starostne strukture zasebnih lastnikov gozdov na način izvedbe poseka in spravila.

Kljub temu, da so moški lastniki posekali več kot dve tretjini skupnih absolutnih količin poseka, ni opaziti večjih razlik v intenziteti sečnje glede na spol lastnika. So pa ugotovljene razlike glede na glavni namen gospodarjenja z gozdom, in sicer so ženske lastnice bolj ekološko usmerjene in manj tržno kot moški. To ugotovitev bi bilo smiselno v prihodnje bolj natančno preučiti, kot tudi še nekatere druge socio-demografske/ekonomske kazalnike, kot so starost in status zasebnega lastnika, tip prebivališča, razdrobljenost posesti.

\section{POVZETEK}

\section{SUMMARY}

The share of private forests and the number of private forest owners in Slovenia have increased in recent decades. With such a large proportion of private forests, an important question arises as to who actually carries out the work in private forest. Previous research in Slovenia has shown that most of the work in the forest is done by the owners themselves, with the help of family members or as part of neighbourly help. Nowadays, however, not all forest owners can be expected to carry out the work in their own forest, nor are they properly equipped and trained to do so. Researchers abroad have shown that private forest owners are motivated to carry out logging and harvesting by a variety of factors, and that the decision to do so is usually a compromise between different desires and needs, while the management method results from their response to changing circumstances and the incentives or barriers that the environment offers them. In order to determine the situation regarding forest operations in private forests, we conducted a survey among randomly selected households throughout Slovenia. By surveying forest owners, we aimed to test the following hypotheses: 1) the size of forest holdings affects the intensity of private forest management; 2) larger private forest owners ( 5 ha or more of forest ownership) are more likely to hire a forestry contractor than smaller private forest owners; and 3) male forest owners manage the forest more intensively than female forest owners and are also more market oriented.

The questionnaire was designed to determine the characteristics of forest operations in private forests in Slovenia and was divided into two parts. The first part was answered by all households and the second part only by those who own forest. A total of 2,883 households participated in the survey, 544 of which were forest owners. Of these, 499 provided all the answers needed to carry out the analysis. Sixty per cent of the owners were men, and they owned 2,350 ha of forests or $75 \%$ of the whole reported forest area. The average age of the surveyed forest owners was 54 years. More than half of the forest owners owned a forest estate ranging from 1 to 4.99 ha. For $62 \%$ of respondents, the primary purpose of forest management is to harvest wood for their own needs. In 2015-2019, 71 \% of respondents carried out felling and skidding in their own forests. A total of 
slightly less than $50,000 \mathrm{~m}^{3}$ of wood was felled, representing an average of $24 \mathrm{~m}^{3} /$ ha and $144 \mathrm{~m}^{3}$ per estate. In absolute terms, the most active were large forest owners (over 30 ha of forest). Relatively speaking, the largest volume was felled by private forest owners with small forest holdings (up to 0.99 ha of forest), on average 41.4 $\mathrm{m}^{3} /$ ha (SD $=49.3 \mathrm{~m}^{3} / \mathrm{ha}$ ). The statistical test revealed that there were statistically significant differences in the volume of felling between the size of the forest holding $\left(\chi^{2}=43.603, p<0.001\right)$ and the average volume of felling. Furthermore, the Welch test showed that there were no statistically significant differences in felling intensity between male and female forest owners.

For all respondents, work done by themselves or with family members predominates, with an average of two or three people working in the forest. The results on the number and age of people indicate intergenerational cooperation in forest work, where both younger and older people are present. Most of them (65\%) learned how to work in the forest from their own experience or knowledge transfer. Approximately $27 \%$ of respondents hired professional forestry contractors, of which those who owned between 5 and 10 ha of forest predominate. According to the survey, we estimate that in 2015-2019 forestry contractors felled more than $20,000 \mathrm{~m}^{3}$ of wood, representing more than $40 \%$ of the total harvesting amount. The main reasons that respondents specified for hiring a forest contractor were the complexity of work ( $40 \%$ ) followed by the lack of work equipment and personal protective equipment. When choosing a contractor, the quality of the implemented work was the most important (44\%) factor in the decision, followed by honesty at $37 \%$. The statistical test showed that there are statistically significant differences between the size of the private forest estate and the method of felling and harvesting $\left(\chi^{2}=13.195, \mathrm{df}=2, p\right.$ $<0.05$ ). Based on the analysis of Pearson's remains, a positive association is shown in the group of larger private owners who carried out felling and harvesting independently and with hired contractors. A positive association is also evident in the group of smaller private owners who carried out felling and harvesting entirely independently without the help of hired contractors.

The survey showed that the size of private forest holdings affects the intensity of management in private forests. The average felling per hectare was highest among small private forest owners (up to $0.99 \mathrm{ha}$ ) and lowest among private forest owners with forest holdings between 10 and 29.99 ha. Thus, we confirmed the first hypothesis. The survey further revealed that there are statistically significant differences between the size of a private forest estate and the method of fel- ling and harvesting. There was a positive interaction in the group of private owners, who own an area of up to 4.99 ha and carry out felling and harvesting independently without the help of hired contractors. A positive interaction is also noticeable in the group of forest owners who own an area larger than 5 ha and carry out felling and harvesting partly independently and partly with the help of hired contractors. Larger owners, with a forest estate of 30 ha or more, carried out only $25 \%$ of the felling on their own or with the help of family members. Sixty eight per cent of larger owners with forest estates of 30 ha or more performed $80 \%$ to 90 $\%$ of all felling and skidding in the forest with the help of hired contractors. The largest proportion of owners performing all work (100\%) with the help of hired contractors was in the 5 to 10 ha size class of forest estates. This confirmed the second hypothesis.

Based on a sample of private forest owners included in the survey, we did not confirm statistically significant differences in felling intensity between genders. Consequently, we rejected the third hypothesis. The results showed that male private forest owners felled as much as $85 \%$ of the total amount of felling in the period 2015-2019, i.e. male owners felled on average $25.4 \mathrm{~m}^{3}$ / ha of wood and female owners $22.4 \mathrm{~m}^{3} / \mathrm{h}$. According to the gender of the private forest owner, the research confirmed statistically significant differences with regard to the main purpose of forest management. In both genders, the use of wood for their own needs predominates. However, there is a positive association among female forest owners who have inherited the forest and do not have a special purpose of managing it, or the main purpose of management is nature protection.

\section{ZAHVALA}

\section{ACKNOWLEDGEMENTS}

Prispevek je nastal v okviru raziskovalnega projekta Razvoj kazalcev in metodologije spremljanja ponudbe gozdarskih storitev (V4-1812), ki ga sofinancirata Ministrstvo za kmetijstvo, gozdarstvo in prehrano ter Agencija RS za raziskovalno dejavnost. Zahvaljujemo se recenzentoma za pregled in predloge izboljšav besedila.

\section{VIRI}

8 REFERENCES

Aguilar F., Cai Z., D'Amato A. 2014. Non-industrial private forest owner's willingness-to-harvest: How higher timber prices influence woody biomass supply. Biomass and Bioenergy, 71: 202-215.

Andersson M., Gong P. 2010. Risk preferences, risk perceptions and timber harvest decisions - an empirical study of nonindustrial private forest owners in northern Sweden. Forest Policy and Economics, 12: 330-339. 
Andersson E., H. Keskitalo E.C. 2019. Service logics and strategies of Swedish forestry in the structural shifts of forest ownership: challenging the "old" and shaping the "new". Scandinavian Journal of Forest Research, 34, 6: 508-520.

Bashir A., Sjølie H.K., Solberg B. 2020. Determinants of nonindustrial private forest owners' willingness to harvest timber in Norway. Forests, 11: 60: DOI.org/10.3390/f11010060

Beach R.H., Pattanayak S.K., Yang J.-C., Murray B.C., Abt R.C. 2005. Econometric studies of non-industrial private forest management: a review and synthesis. Forest Policy and Economics, 7: 261-281.

Češarek D., Ficko A., Bončina A. 2018. Vplivni dejavniki poseka v zasebnih gozdovih Slovenije v obdobju 1995-2014. Acta Silvae et Ligni, 115: 29-42.

Eggers J., Lämås T., Lind T., Öhman K. 2014. Factors influencing the choice of management strategy among small-scale private forest owners in Sweden. Forests, 5, 1695-1716.

Erlandsson E. 2016. The triad perspective on bisiness models for wood harvesting. Doctoral Thesis. Swedish University of Agricultural Sciences, Acta Universitatis Agriculturae Sueciae, 124: 1652 -6880.

Ficko A. 2019. Private forest owners' social economic profiles weakly influence forest management conceptualizations. Forests, 10: 956: DOI.org/10.3390/f10110956

Häyrinen L., Mattila O., Berghäll S., Toppinen A. 2015. Forest owners socio-demographic characteristics as predictors of customer value: evidence from Finland. Small-scale Forestry, 14: 19-37.

Juutinen A., Tolvanen A., Koskela T. 2020. Forest owners' future intentions for forest management. Forest Policy and Economics, 118: 102220

Kilham P., Hartebrodt C., Schraml U. 2019. A conceptual model for private forest owners' harvest decisions: a qualitative study in southwest Germany. Forest Policy and Economics, 106: 101971.

Korbar U. 2005. Gozdarstvo kot neizkoriščena priložnost na področju razvoja podeželja. V: Kavčič S. (ur.). Slovenija v EU - izzivi za kmetijstvo, živilstvo in podeželje (3. konferenca DAES, Moravske Toplice, 10.-11. november 2005). 1. izd. Ljubljana, Društvo agrarnih ekonomistov Slovenije - DAES: 97-108.

Kumer P. 2019. Lastniki gozdov v Sloveniji. (Knjižna zbirka Georitem, 30). 1. izd. Ljubljana, Založba ZRC: 123 str.

Kumer P., Pezdevšek Malovrh Š. 2019. Factors hindering forest management among engaged and detached private forest owners: Slovenian stakeholders' perceptions. Small-scale Forestry, 18: 105-125.

Kuuluvainen J., Karppinen H., Hänninen H., Uusivuori J. 2014. Effects of gender and length of land tenure on timber supply in Finland. Journal of Forest Economics, 20: 363-379.

Mattila 0., Roos A. 2014. Service logics of providers in the forestry services sector: evidence from Finland and Sweden. Forest Policy and Economics, 43: 10-17.

Medved M. 2003. Posestne razmere in pridobivanje lesa v zasebnih gozdovih. Gozdarski vestnik, 61, 9: 347-359.

Medved M. 1991. Vključevanje lastnikov gozdov v gozdno proizvodnjo: magistrsko delo. (Univerza v Ljubljani, BF, Oddelek za gozdarstvo in obnovljive gozdne vire). Ljubljana, samozaložba: 179 str.

Medved M. 2000. Importance of knowledge for small scale forest ownwers. V: BEGUŠ, Jurij (ur.), ANDERSON, Jon (ur.), BECK, Roland L. (ur.). Working under a dynamic framework - forest ownership structures and extension: proceedings. Ljubljana, Zavod za gozdove Slovenije: 174-188.

Molnar J.J., Schelhaas J., Carrie H. 2007. Nonindustrial private forest landowners and the southern pine beetle: factors affecting monitoring, preventing, and controlling infestations. Southern Journal of Applied Forestry, 31: 93-98.

Nichiforel L., Keary K., Deuffic P., Weiss G., Thorsen B.J., Winkel G., Avdibegović M., Dobšinská Z., Feliciano D., Gatto P., Gorriz Mifsud E., Hoogstra-klein M., Hrib M., Hujala T., Jager L., Jarský V., Jodłowski K., Lawrence A., Lukmine D., Pezdevšek Malovrh Š., Nedeljković J., Nonić D., Krajter Ostoić S., Pukall K., Rondeux J.,
Samara T., Sarvašová Z., Scriban R.E., Šilingienė R., Šinko M., Stojanovska M., Stojanovski V., Stoyanov N., Teder M., Vennesland B., Vilkriste L., Wilhelmsson E., Wilkes-Allemann J., Bouriaud L. 2018. How private are Europe's private forests?: A comparative property rights analysis. Land Use Policy, 76: 535-552.

Nordlund A., Westin K. 2011. Forest values and forest management attitudes among private forest owners in Sweden. Forests, 2: 30-50.

Novais A., Canadas M.J. 2010. Understanding the management logic of private forest owners: a new approach. Forest Policy and Economics, 12: 173-180.

Petucco C., Abildtrup J., Stenger A. 2015. Influences of nonindustrial private forest landowners' management priorities on the timber harvest decision - a case study in France. Journal of Forest Economics, 21: 152-166.

Pezdevšek Malovrh Š., Zadnik Stirn L., Krč J. 2010. Influence of ownership and property structure on willingness of private forest owners to cooperate. Šumarski list, 134: 3-4.

Pezdevšek Malovrh Š. 2010. Influence of institutions and forms of cooperation on private forest management: doctoral dissertation. (Univerzity of Ljubljana, Biotechnical Faculty, Department of Forestry and Renewable Forest Resources). Ljubljana, samozaložba: 240 str.

Pezdevšek Malovrh Š., Nonić D., Glavonjić P., Nedeljković J., Avdibegović M., Krč J. 2015. Private forest owner typologies in Slovenia and Serbia: targeting private forest owner groups for policy implementation. Small-scale Forestry, 14, 4: 423-440.

Poje A., Pezdevšek Malovrh Š., Krč J. 2016. Factors affecting harvesting intensity in small-scale private forests in Slovenia. Smallscale Forestry, 15: 73-91.

Poročilo Zavoda za gozdove Slovenije o gozdovih za leto 2019. 2020 Zavod za gozdove Slovenije. http://www.zgs.si/fileadmin/zgs/ main/img/PDF/LETNA_POROCILA/2019_Porocilo_o_gozdovih. pdf (8. 4. 2021)

Program razvoja gozdov v Sloveniji. 1996. Ur. l. RS, št. 14/96.

Robek, R., Klun, J., Krajnc, N., Mavsar, R., Ogris, N., Piškur, M., Medved, M., Bogataj, N. 2005. Removing barriers for forest operation improvements among non-inustrial private forest owners in Solčava (Northern Slovenia). V: Robek R., Arzberger U. (ur.). Forest operation improvements in farm forestry in Slovenia : workshop proceedings : Logarska Dolina, Slovenia, 9-14 September 2003. Rome: Food and agriculture organization of the United nations: 177-186.

Rutar M. 2010. Opremljenost lastnikov gozdov pri sečnji v Gozdnogospodarski enoti Tolmin: diplomsko delo. (Univerza v Ljubljani, Biotehniška fakulteta, Oddelek za gozdarstvo in obnovljive gozdne vire). Ljubljana, samozaložba: 54 str.

Statistični urad RS - Podatkovna baza Gozdarstvo na kmetijskih gospodarstvih. 2021. Število opravljenih delovnih ur v gozdarstvu na kmetijskih gospodarstvih, Slovenija, za leto 2016. https:// pxweb.stat.si/SiStatData/pxweb/sl/Data/-/1679110S.px (8. 4. 2021).

Triplat M., Krajnc N. 2021. A system for quality assessment of forestry contractors. Croatian Journal of Forest Engineering, 42, 1: 77-90.

Westermayer T. 2006. Out-sourcing of work in Germany's forestry: rural social structure and identity in transformation. Freiburg, Albert-Ludwigs-Universität Freiburg im Breisgau: 28 str.

Winkler I. 1976. Sedanje stanje in temeljni problemi gospodarjenja $\mathrm{z}$ zasebnimi gozdovi v SR Sloveniji. Zbornik gozdarstva in lesarstva, 14, 2: 123-154.

Zakon o gozdovih. 1993. Ur. l. RS, št. 30/93, 56/99 - ZON, 67/02, 110/02 - ZGO-1, 115/06 - ORZG40, 110/07, 106/10, 63/13, 101/13 - ZDavNepr, 17/14, 22/14 - odl. US, 24/15, 9/16 ZGGLRS in 77/16.

ZGS (Zavod za gozdove Slovenije). 2020. Interni podatki o strukturi zasebnih lastnikov gozdov. 